\title{
THE “HEART” COMPONENT IN THE CONCEPT OF “THOUGHTFUL”
}

\author{
Zohida O. Amirova
}

Lecturer Karshi State University Uzbekistan

\section{ABSTRACT}

The heart is the center of the human body. It determines the work of other parts of the human body, it nourishes, gives life. Perhaps it is this extraordinarily important aspect of the heart that has led it to be likened to the center of something, to the orientation of space, in both languages being studied.

KEYWORDS: - Thinker, insanity, a man busy with his imagination, wisdom, brain, gentle.

\section{INTRODUCTION}

It should be noted that in the Uzbek language, the component "heart" is directly part of the concept of "thinking". Not through the head (as in English), but through the heart, all thought processes take place [1]. The movement "Thinking", "Thinking" itself is presented in Uzbek as follows:

Its semantic field includes the following lexemes:

- thinker- o'ylovchi;

- place of consultation- maslahat o'rni;

- contemplative images / styles- tafakkur obrazi/uslubi;

- insanity- aqlsizlik;

- foolish- aqlsiz;

- thinking, thought- fikrlash, fikr;

- a man busy with his imagination- o'z hayollari bilan band odam;

- dark, strange thoughts- tund, galati fikrlar;
- anxious, thoughtful- tashvishlangan, o'ychan;

- thoughtfully disappointed- o'ychan ma'yus;

From a logical point of view, a concept is a set of characteristic characters plus the total volume of objects that have such characters. "The concept emphasizes the generality achieved by removing all the features of individual objects ..." (BSE 1974). At the same time, scientific concepts and non-scientific (vital) concepts are distinguished. For example, when a villager talks about a pig, he does not bother about the fact that this animal belongs to the group of ungulates in the family of pigs and other aspects. Such characters are of interest not only to the pig farmer, but also to the scientist engaged in theoretical research.

\section{THE MAIN RESULTS AND FINDINGS}

\section{CURRENT RESEARCH JOURNAL OF PHILOLOGICAL


CURRENT RESEARCH JOURNAL OF PHILOLOGICAL SCIENCES 2(12):

17-20, December 2021

DOI: https://doi.org/10.37547/philological-crjps-02-12-04

ISSN 2767-3758

(C2021 Master Journals

Crossref do

8 Google

Accepted05 ${ }^{\text {th }}$ December, 2021 \& Published 10 ${ }^{\text {th }}$ December, 2021

Thus, if the notion of a concept as a general one, which is traditional for logic (BSE, 1974), can be considered as part of a concept, as many researchers think (Apresyan 2001: Karasik 2002) . Kubryakova 1992. Likhachyov 1993. Teliya 1996. Cherneyko 1997 and many other researchers).

There is no doubt that the concept of "Юрак" ("heart") is active in the formation of various "thinking" concepts, because they all pass through the heart.

The Uzbek language has a special place in the worldview:

Think, speak, look around, and sit down.

If you want to talk once, think twice.

There is another concept related to the concept "wisdom".

- smart, thoughtful, intelligent- aqlli, mulohazali, zukko;

- $\quad$ intellect, perception- aql, idrok;

- $\quad$ smart, silly- aqlli, be'mani.

Apparently, the word also means "mind." It is also used in the sense of "brain" in the head. Z.X. As Bijeva points out, the concept is romantically close to the meaning of "common sense."

"Wisdom also comes from common sense through mutual experience. It is the way people look at the world around them and themselves, these actions and deeds. Wisdom and right thinking are confronted with a concept that most people encounter, which is generally known to all, i.e., what they see, hear, and know. But common sense accepts all this as natural, manifesting itself without any reflexes, and wisdom is not a set of data, but a high spiritual zeal that synthesizes all forms of human cognition ("global reflection") and an active attitude towards man $(107,122)$. "Thinking" is higher than "common sense":

The mother of the mind is contemplation.

Thus, leadership is given to the process of thinking more than pure intellect, perception.

The participation of the concept of "heart" in the structure of the following concepts shows that "heart" is associated with the process of understanding:

- understanding, agreement, implementationtushunish, kelishish, amalga oshirish;

- understanding- tushunish;

- resourceful, easily assimilated- topqir, yengil o'zlashtiriluvchi;

- understandable- tushunarli;

- difficult to accept- qiyinchilik bilan qabul qilinuvchi;

In Uzbek science, thinking is directly related to the "heart", the processes of thinking take place in the head. However, thoughts may also arise in the "heart":

Secret penetration into the heart (feelings, thoughts) - invisible, hidden, unwanted appearance, occurrence;

Reading in the heart (in the heart) - finding someone's dreams, desires, moods;

Heartbreak- 1) to appear (about feelings, moods, thoughts); 2) to turn on, to see well;

The peculiarity is that thoughts appear suddenly, the process of thinking itself does not take place in the "heart".

English to lay smth to heart - to think, to get close to the heart; to bring to someone's consciousness; trying to fit into the mind (e.g., putting something in the heart) - all of this connects the "heart" with the process of thinking, but this is not entirely consistent with the concepts of "thinking" and "thinking". 
CURRENT RESEARCH JOURNAL OF PHILOLOGICAL SCIENCES 2(12):

17-20, December 2021

DOI: https://doi.org/10.37547/philological-crjps-02-12-04

ISSN 2767-3758

(C)2021 Master Journals

Crossref do

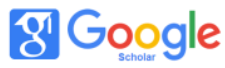

Accepted05 ${ }^{\text {th }}$ December, 2021 \& Published 10 ${ }^{\text {th }}$ December, 2021

read people's hearts.

Secret thoughts are stored in the heart, not through thinking.

The "heart" component in the "memory" concept. In the Uzbek Academy of Sciences, information is stored in the "heart" and remembered.

Thus, the heart of a compassionate person should also be "compassionate", "soft", "tender", "gentle". "Merciful heart" cares for others, in the Uzbek language, he "shrinks" by loving others. In the English OLM, the "place" of the heart is emphasized - it must be in the "right" place. English is associated with "compassionate" heart "gold" in the world. Apparently, the choice of metal is not in vain, because gold has been one of the most precious metals for centuries [2].

In the language scenes seen, an indifferent, naughty, rude person is described as follows:

This is the case in Uzbek

- insensitive heart (eg, fat heart- tuyg'usiz yurak (ayn.: semiz yurak);

dilsiz (ayn.: tishlashlarsiz).

- cold heart, dull, indifferent (eg, cold heart)- yuragi

sovuq, nokas, befarq (ayn.: sovuq yurak);

- ruthless- rahmsiz shavqatsiz;

- dumb (e.g. without teeth)- rahmsiz shavqatsiz;

So in English

a heart of flint (of stone);

harden smb's heart;

a hard heart;

headless;

cold hearted;

hard-hearted- hard, insensitive;

stony-hearted- stone (literally: stone).

The following symbols are given in the Uzbek

language OLM:

Heartless- careless; dumb;

ruthless,

moldy heart- heartless, numb.
At the present stage of development of the science of linguistics, the study of language only as a means of communication is becoming a somewhat outdated narrow concept. A different approach to language that allows us to define its essence requires looking at it not only as a means of communication but also as an integral part of folk culture. The concepts of language-consciousnessculture are closely intertwined and require study in an organic connection.

Changing the focus of study leads to the emergence of confusing fields of different character: ethnopsychology, psycholinguistics, cognitive psychology, sociolinguistics, cognitive linguistics, ethnolinguistics. The tasks of linguoculturology are to describe the study of the relationship between language and culture, language and national mentality.

\section{Conclusion}

Language, thought and culture are so interdependent that in practice they form a whole, they cannot exist without each other. Together, they interact with the world around them, reflect it, and, at the same time, shape it. In doing so, they create a linguistic landscape of a specific world - a model of a systematically ordered social character that conveys specific information about the world around them - using a variety of linguistic means. In the linguistic landscape of the world, ethnic mentality is a verbal symbol of "perfect" concepts in leading cultural concepts - defined by a system of known cultures, customs and traditions within the concept "etymologized" by the internal form of the word that expresses it. the image is updated. This makes the concept one of the conceptual apparatus of the core terms of culturological linguistics. Linguospecific concepts simultaneously shape and reflect the thinking image of language representatives. 
CURRENT RESEARCH JOURNAL OF PHILOLOGICAL SCIENCES 2(12):

17-20, December 2021

DOI: https://doi.org/10.37547/philological-crjps-02-12-04

ISSN 2767-3758

(C)2021 Master Journals

crossref do) :810 Google

Accepted05 ${ }^{\text {th }}$ December, 2021 \& Published 10 ${ }^{\text {th }}$ December, 2021

Appendix

Yurak urishi;

Yurak shaklidagi - shaklan yurakni eslatuvchi;

Yurak yaqinidagi- yurak atrofida joylashgan;

Yurak xasta- bemor;

The following terms are available in English:

heart- attack- yurak xuruji;

heart - beat- yurak urushi;

heart- failure- yurak falaji;

heart block - yurak blokadasi;

heart massage- yurak uqalashi;

heart monitor- yurak monitori;

heart murmur- yurakdagi shovqin;

heart muscle- yurak mushagi;

heart valve- yurak klapani;

heart line- yurak konturi;

athlete's heart- yurak gipertrofisi;

artificial heart- sun'iy yurak;

atrium of the heart- yuraqoldi;

\section{- 1990. No. 4. -WITH. 62-87.}

6. Humboldt V. Language and philosophy of culture. -M .: Progress. -1985. - 451s (Linguists of the world).

7. Humboldt V. Selected works on linguistics / Per. with him. Common ed. T.V. Ramishvili, after. A.V. Gulygi and V.A. Zvegitseva, - M .: OAOIG "Progress". -2000. -400s.

\section{RefERENCES}

1. Vendina T.N. Word formation and "concealment of meanings" of the language of culture /. Moscow State University Bulletin. Ser. 19. Linguistics and intercultural communication. -M., 2001, -S. 14-31.

2. Vinogradov V.V. Russian language (grammatical teaching about the word). Ed. 2. - M .: Higher school, 1972 .-- 614 p.

3. Vorkachev S.G., Kusov G.V. The concept of "insult" and its etymological memory // Theoretical and Applied Linguistics. Language and social environment. Voronezh: Publishing house of VSTU, 2000. Vyp. 2. - S. 90-102.

4. Vorkachev S.G. Linguoculturology, linguistic personality, concept: the formation of the anthropocentric paradigm in linguistics Philological sciences. - 2001 .-- S. 64-71.

5. Vysheslavtsev B.P. Heart in Christian and Indian mysticism // Problems of Philosophy. 